\title{
UMGT 用実機型水素燃料極超小型燃焼器の燃焼特性*
}

\author{
笛田 剛 志*1, 桜井毅 司*2, 湯 浅三 郎*2 \\ Combustion Characteristics of an Engineering-Model \\ of Hydrogen-Fueled Ultra-Micro Combustor for UMGT
}

\author{
Takeshi FUEDA*3, Takashi SAKURAI and Saburo YUASA \\ ${ }^{* 3}$ Department of Aerospace Engineering, Tokyo Metropolitan University, \\ 6-6 Asahigaoka, Hino-shi, Tokyo, 191-0065 Japan
}

\begin{abstract}
An engineering-model of hydrogen-fueled flat-flame ultra-micro combustor with a combustion chamber volume of $69.4 \mathrm{~mm}^{3}$ was developed. The burning test of the combustor showed that it was easy to ignite and burn with a stable flame. Both the stable flame region and the ignition limit were enough wide to satisfy the design operation point of the combustor. The engineering-model combustor attained high combustion efficiency with a pressure loss around $5 \%$. $\mathrm{NO}_{x}$ emissions were extremely low of less than $3 \mathrm{ppm}$.
\end{abstract}

Key Words: UMGT, Flat-Flame Ultra-Micro Combustor, Engineering-Model, Hydrogen

\section{1. はじめに}

超小型モバイル電子機器や無人航空機, ロボッ ト等への搭載を目的とした動力源としてウルト ラマイクロガスタービン(UMGT)の開発が進めら れている(1). 筆者らは, UMGT サイズの極超小型 燃焼器の研究開発を行ってきた。これまでに,こ のような微小空閒内での然焼方式として Flat-flame 燃焼方式が適していることを提案し(2), 水素を燃料とする試験燃焼器を用いた燃焼実験 より，この燃焼方式が低圧力損失のもと，高い火 炎安定性上高燃焼効率及び高燃焼負荷率老実現 できることを実証している(3).

次の段階として, UMGTに搭載可能な極超小型 燃焼器開発の問題点を抽出・明確化し, 高負荷な 極超小型燃焼器を設計・試作することを目的に， 実機型のUMGT 用 Flat-flame 型極超小型燃焼器を 試作した ${ }^{(4)}$. 本報告では, 燃焼実験より得られた, 二の実機型燃焼器の火炎安定性や燃焼効率等の 燃焼特性について述べる。

\section{2. 実験装置及び方法}

\section{1 実機型然焼器試作した極超小型燃焼} 器の概略を図 1 に示す. 燃焼室は, 直径 $9.4 \mathrm{~mm}$,

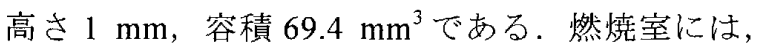
機械的強度を保ちつつ熱損失を極力低減できる

$*$ 原稿受付 2009 年 9 月 24 日.

*1 首都大学東京大学院シスデムデザイン研究科航空宇宙シス テム工学域 (要 191-0065 日野市旭が丘 6-6).

*2 正員, 首都大学東京大学院システムデザイン研究科航空宇宙 システム工学域.

E-mail : fueda@ asyat5.tmit.ac.jp
ように耐熱性に優れたセラミックスの LOTEC-TM を用い，燃焼器外壁には金属の中で も比較的耐熱性があり熱伝導率も低いステンレ ス，それらの間には非常に熱伝導率の低い MICROSIL (ZIRCAR 製) を断熱材として挿入し, 3 層構造とした。

2.2 実験条件および方法実験は常温，大 気圧下で行った。このときの設計稼動条件は, 当 量比 $=0.4$, 空気流量 $=0.037 \mathrm{~g} / \mathrm{s}$ である。これは MIT 設計值を参考にした(1)。着火は，燃焼室内部に抻 入した極細線のスパークプラグによっで行った。 温度は燃焼室出口 (F), 排気スリット出口 $(\mathrm{E})$, 外壁の A,B,C 点 (図 1 参照) の合計 5 点を計測し た、計測に用いた熱電対は，素線径 $0.2 \mathrm{~mm} の \mathrm{~K}$ 型熱電対である.燃焼ガスは, 排気スリット出口 に設置した微細孔を有する石英ガラスプローブ で採取し，水分を除去した後，水素濃度計と NOx 濃度計で計测した。 また，予混合気流入部の上流 に圧力計を設置し, 燃焼器圧力損失の評価に用い te.

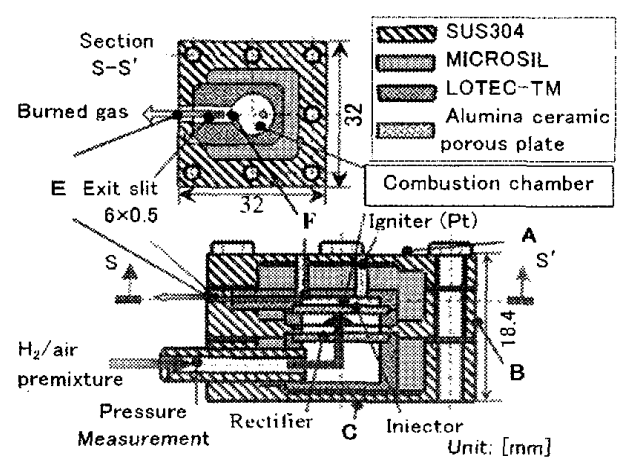

Fig.1 Schematic of the engineering-model of hydrogen-fueled flat-flame ultra-micro combustor 


\section{3. 実験結果及び考察}

図 2 に設計稼動条件下で測定した燃焼器各部の 温度履歴を示す. 熱電対からの輻射及び熱伝導に よる熱損失の補正は行っていない. 本燃焼器の着火 は，容易に行うことができた。燃焼室出口温度は $1310 \mathrm{~K}$, 燃焼器出口 $980 \mathrm{~K}$, 外壁温度 $\mathrm{A}$ 点 $550 \mathrm{~K}$, $\mathrm{B}, \mathrm{C}$ 点 $510 \mathrm{~K}$ でほぼ一定值となった。この時の燃焼 室出口温度は, 当量比 $=0.4$ に打仔予熱なしの水素 /空気予混合気の断熱火炎温度 $1425 \mathrm{~K}$ 上り $100 \mathrm{~K}$ 程度低い.しかし, 熱電対からの熱損失が $100 \mathrm{~K}$ 程 度あると考えられ，燃焼室内ではほぼ完全然焼が達 成できていることが期待できる．この場合の燃焼負荷 率は $7300 \mathrm{MW} /\left(\mathrm{m}^{3} \cdot \mathrm{MPa}\right)$ となり，一般の小型燃焼 器と比べて非常に高い, 一方, 本燃焼器は熱容量 が大きく，元の時定数は大きい。今後, 燃焼器の 時定数を小さくするために，ステンレスの外壁を 極力薄くして，時定数を小さくする必要がある.

実験回数を重衫焼の積算時間が増加すると， 燃焼室壁を構成する LOTEC-TM 部品が割れ易く なることがわかった。これは，着火・消炎時の急 激な温度上昇・降下による熱衝撃や長時間の燃焼 による熱応力が原因であると考えられる.そこで， この部分の材質を機械強度の高いステンレスに 変更した場合についても実験を行った。

図 3 に実機型燃焼器 (燃焼室壁に LOTEC-TM を用いた場合とステンレスを用いた場合）の着火 限界と火炎安定限界の測定結果を, 試験然焼器の 結果 ${ }^{(2.3)}$ と比較して示す。実機型燃焼器は, LOTEC-TM とステンレスのどちらを用いた場合 でも，試験燃燒器と同様に設計点を十分に満たし， 広範囲にわたって高い火炎安定性を示した。着火 範囲は，火炎安定限界と同じ傾向であった。しか し，火炎安定限界よりも高い当量比が必要である ことがわかった。これは，着火時に常温の燃焼室 壁面に扝ける消炎効果が大きいためと考えられ る. 改善策として, 燃焼室に断熱性の高い材料を 使用するなどの対策が必要である。設計稼動条件 下において，圧力損失率は 5.6\%であった。圧力 損失が大きい箇所として, 燃焼器内で流路面積が 最も小さい排気スリットが举げられる。この対策 として, 流路面積を大きくするといった工夫が必 要である。

本然焼器は LOTEC-TM とステンレスのどちら を用いた場合でも，設計稼動条件である当量比 0.4 よりも大きい範囲で $99.3 \%$ 以上燃焼効率を 達成した。さらに、より希薄な当量比 0.35 付近

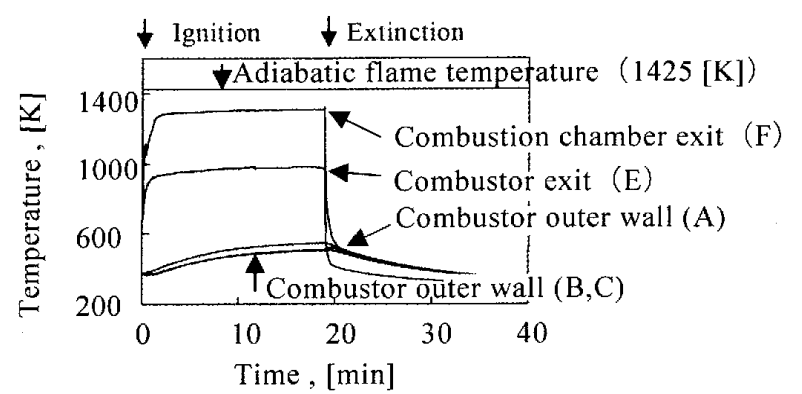

Fig.2 Time record of temperatures at the combustion chamber exit, the combustor exit and the outside of the stainless steel walls $\left(\dot{m}_{a}=0.037[\mathrm{~g} / \mathrm{s}], \varphi=0.4\right.$ )

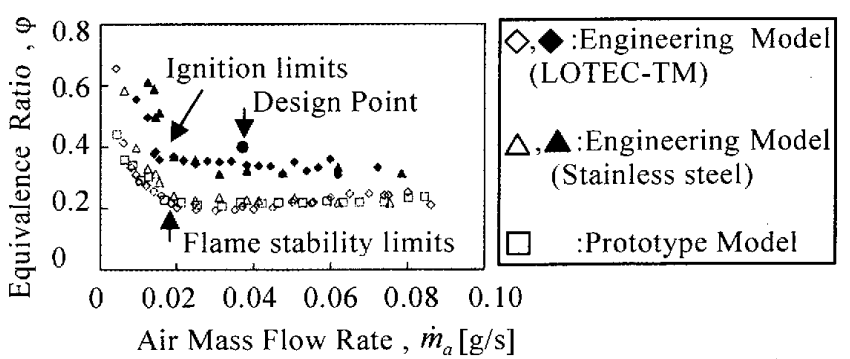

Fig.3 Flame stability and ignition limits of the engineering models (LOTEC-TM, Stainless Steel) and the prototype model of ultra-micro combustor

まで 95\%以上の良好な燃焼効率であった。NOx 濃度については, 実験の範囲（当量比 $=0.30 \sim$ 0.58）に扎いて，3ppm 以下と非常に小さい值で あった，本燃焼器は設計稼動条件において極めて 高負荷な燃焼のもとで, 完全燃焼と極低 NOx を 達成した。

\section{4. まとめ}

試作した flat-flame 燃焼方式の UMGT 用害機 型極超小型水素燃料燃焼器 (燃焼室: 高さ $1 \mathrm{~mm}$ 、 容積 $69.4 \mathrm{~mm}^{3}$ ) は, スパークプラグで容易に着 火可能であり，その着火および火炎安定範囲は設 計点を満たし広範囲である。また, 極めて高負荷 な燃焼と，良好な燃焼効率を $5 \%$ 程度の圧力損失 率で達成した。 NOx 濃度は 3 ppm 以下と極めて 微量であった。

なお本研究仕，科研費基盤研究（B）

(No.19360383) の助成を受けた。ここに記して 謝意在表す。

\section{参考文献}

(1) Epstein, A. H. et al., AIAA 97-1773 (1997).

(2) Yuasa, S., Oshimi, K., Nose, H., Tennichi, Y.: Proc. Combust.Inst.Vol.30,No.2(2004),pp.2455-2462

(3) Yuasa, S., Sakurai, T., Shimotori, S., Wong, S.F.: Proc. $18^{\text {th }}$ ISABE 2007-1167 (2007).

(4) Shimotori, S., Yuasa, S., Sakurai, T.: Proc. AJCPP 2008, D6-2, (2008). 